\title{
"PRICE RIVALRY IN AIRLINE MARKETS: A STUDY OF A SUCCESSFUL STRATEGY OF A NETWORK CARRIER AGAINST A LOW-COST CARRIER"
}

Xavier Fageda, Juan Luis Jiménez and Jordi Perdiguero GIM-IREA Universitat de Barcelona 


\section{$\overbrace{\circledast}^{\oplus}|\mathrm{R}| \mathrm{E}|\mathrm{A}|$}

Institut de Recerca en Economia Aplicada Regional i Pública Research Institute of Applied Economics

\section{Universitat de Barcelona}

Av. Diagonal, $690 \bullet 08034$ Barcelona

WEBSITE: www.ub.edu/irea/•CONTACT: irea@ub.edu

The Research Institute of Applied Economics (IREA) in Barcelona was founded in 2005, as a research institute in applied economics. Three consolidated research groups make up the institute: $A Q R$, RISK and GiM, and a large number of members are involved in the Institute. IREA focuses on four priority lines of investigation: (i) the quantitative study of regional and urban economic activity and analysis of regional and local economic policies, (ii) study of public economic activity in markets, particularly in the fields of empirical evaluation of privatization, the regulation and competition in the markets of public services using state of industrial economy, (iii) risk analysis in finance and insurance, and (iv) the development of micro and macro econometrics applied for the analysis of economic activity, particularly for quantitative evaluation of public policies.

IREA Working Papers often represent preliminary work and are circulated to encourage discussion. Citation of such a paper should account for its provisional character. For that reason, IREA Working Papers may not be reproduced or distributed without the written consent of the author. A revised version may be available directly from the author.

Any opinions expressed here are those of the author(s) and not those of IREA. Research published in this series may include views on policy, but the institute itself takes no institutional policy positions. 


\begin{abstract}
Competition in airline markets may be tough. In this context, network carriers have two alternative strategies to compete with low-cost carriers. First, they may establish a low-cost subsidiary. Second, they may try to reduce costs using the main brand. This paper examines a successful strategy of the first type implemented by Iberia in the Spanish domestic market. Our analysis of data and the estimation of a pricing equation show that Iberia has been able to charge lower prices than rivals with its low-cost subsidiary. The pricing policy of the Spanish network carrier has been particularly aggressive in less dense routes and shorter routes.
\end{abstract}

JEL classification: L13, L59, L71

Keywords: Airlines, competition, low-cost carriers

Xavier Fageda is Lecturer at Universitat de Barcelona. Department of Economics Policy. E-mail: xfageda@ub.edu.

Juan Luis Jiménez from Universidad de Las Palmas de Gran Canaria. Departament of Applied Economic Analysis E-mail: jliimenez@daea.ulpgc.es

Jordi Perdiguero is Associate professor at Universitat de Barcelona. Department of Economics Policy. E-mail: jordi.perdiguero@ub.edu. 


\section{PRICE RIVALRY IN AIRLINE MARKETS: A STUDY OF A SUCCESSFUL STRATEGY OF A NETWORK CARRIER AGAINST A LOW-COST CARRIER}

\section{Introduction}

The liberalization of air transport markets in the USA, Europe, and other countries has led to an increase in airline competition on many routes. This increased competition has been spurred particularly by the success of low-cost airlines.

In Europe, low-cost airlines such as Ryanair, EasyJet, and many others have become major players on short-haul routes. But while the biggest low-cost carriers (LCCs), namely Ryanair and EasyJet, are performing quite well in competition with network carriers, it is not so clear whether smaller LCCs are really able to compete with former flag carriers. In fact, a number of former flag carriers have created low-cost subsidiaries to increase their cost competitiveness on short-haul routes by offering point-to-point services in competition with other LCCs. Recent examples of this strategy in Europe are provided by KLM with Transavia, Lufthansa with Germanwings, and SAS with Snowflakes. In this paper, we analyse Iberia's implementation of this strategy in Spain with the creation of Clickair to compete with the Spanish LCC, Vueling.

In 2006 Iberia, the former Spanish flag carrier, initiated a new business plan that led to the concentration of its operations at its main hub, the airport of Madrid-Barajas. A further measure in this plan was to create a new low-cost airline, Clickair, with an operating base located in the airport of Barcelona-El Prat. Recall that Madrid and Barcelona airports are both among the ten largest airports in Europe in terms of the passenger traffic they handle.

Using Iberia's slots and resources, Clickair soon acquired the largest market share at Barcelona airport. One of the most probable motives for the creation of Clickair was to compete with another Spanish low-cost airline, Vueling, which had become a serious competitor to Iberia in the Spanish domestic market. ${ }^{1}$ In 2009, Clickair and Vueling merged under the name of Vueling. In this new company, Iberia is the major shareholder.

\footnotetext{
${ }^{1}$ A further possible motivation for the creation of Clickair was Iberia's desire to impose an entry barrier on other network carriers like Lufthansa or Air France, should they have wanted to develop hub-and-spoke operations at a large airport, such as Barcelona, close to Madrid. With a big LCC like Clickair, the profitability of the spokes (the short-haul flights meant to feed long-haul flights)
} 
Our empirical analysis, therefore, focuses on a case in which a network airline successfully competed with another low-cost airline through the operating of a low-cost subsidiary. This paper examines Iberia's successful strategy by analyzing price rivalry on Spanish domestic routes departing from Barcelona airport. We use data from the period 2003 to 2009.

The aim of this paper is twofold. First, we seek to identify the type of routes that benefit most from the price rivalry established between Clickair and Vueling, examining route characteristics that include traffic density and distance as well as airline attributes such as their respective market shares. Second, we wish to assess whether Iberia's successful strategy is associated with predatory behaviour.

The remainder of the paper is organized as follows. In the second section, we review the literature most closely related to this study. In the third section, we describe the data used in our empirical analysis. In the fourth section, we examine in detail the statistics describing price rivalry in the Spanish market. In the fifth section, we estimate equations at the route level to explain the determinants of both mean prices and the prices of Iberia (and its partners) in relation to its rivals. The last section is devoted to concluding remarks.

\section{Literature review}

One of the most obvious effects of the liberalization of the airline industry has been the decrease in airfares due to increased competition (Goetz and Vowles, 2009). In this regard, the relationship between airfares and competition has received a great deal of attention in the empirical literature on air transportation.

Since the seminal paper of Borenstein (1989), several studies have examined the influence of market characteristics such as route concentration or airport dominance on airline fares. Applying the pricing equation, the success of LCCs as new entrants has been particularly well documented in the USA. In this market, Southwest has become the airline with the largest market share. Several papers have documented that legacy carriers cut fares on those routes affected by the actual or potential entry of Southwest. Among these studies, mention should be made of those by Dresner et al. (1996), Morrison (2001), and Vowles $(2000,2006)$. From these studies, it seems clear that the entry of an LCC, most 
notably Southwest, on a route leads in general to a reduction in mean prices at that route level.

The effects of the success of LCCs in Europe have also been analysed using a pricing equation. ${ }^{2}$ Alderighi et al. (2004), Fageda and Fernández (2009) and Gaggero and Piga (2010) examine the effect of the presence of low-cost carriers operating on routes in Italy, Spain and United Kingdom on prices, respectively. As in the US case, they similarly report that prices on a route are lower when an LCC starts its operations there.

To date, there has been very little attention dedicated to the circumstances under which a legacy carrier (or a network airline) ${ }^{3}$ might charge lower prices than its low-cost rivals once the latter have entered the route.

It is clear that LCCs are able to exploit several cost advantages on short-haul routes (Graham and Vowles, 2006; Graham et al., 2006). First, low-cost airlines are able to achieve a high utilization of the plane and its crew. Second, they have lower labour costs due to the weaker role played by the unions. Third, they have a simpler management model. This is attributable to the fact that they focus on point-to-point services, use just one type of plane, operate a single fare-class, and provide no free on-board frills. Some LCCs, such as Southwest and Ryanair, also enjoy lower charges from their use of secondary airports.

In this regard, Graham and Vowles (2006) identify two alternative strategies that might permit network carriers to compete with LCCs. First, network carriers can establish lowcost subsidiaries in what the authors call the "carriers within carriers strategy". Second, they can seek to reduce costs by competing against LCCs with their main brand. These strategies might be aimed at responding to the actual entry of an LCC or pre-empting its possible entry.

In this context, there is an increasing convergence of the business models being operated by network airlines and LCCs on short-haul routes. For example, most network airlines provide no-frill services on short haul routes and are gradually eliminating the business fare class on certain routes or simplifying their yield management system. In many cases, they are also establishing franchises with regional airlines that use smaller aircraft. However, it is more difficult for network airlines to reduce their labor costs or to simplify certain aspects of their management systems, such as their distribution practices. For these

\footnotetext{
${ }^{2}$ See Dobruszkes (2009) for a recent analysis of the geography of LCCs in Europe.

${ }^{3}$ The term network airline would be more appropriate in Europe.
} 
latter reasons, it might make sense for a network airline to compete with LCCs by establishing a low-cost subsidiary that fully adopts the low-cost model.

However, Graham and Vowles (2006) undertake a broad examination of the establishment of low-cost subsidiaries by network carriers around the world but fail to find indisputable evidence that this strategy has been successful. In an analysis focused solely on the US experience, Morrell (2005) draws the same conclusion.

It would appear that the difficulties in effectively separating network operations from those of the low-cost subsidiary lead to a cannibalization and dilution of the main brand. Furthermore, network carriers may find it difficult to differentiate the pay scales of employees due to union activism.

However, the successful establishment of low-cost subsidiaries by network carriers could be associated with predatory behaviour. In this regard, Goetz (2002) reports several complaints made by new entrants about the predatory behaviour of incumbent airlines in the US domestic market in the nineties. Such behaviour typically saw incumbent airlines cutting fares to similar or lower levels than those of their new rivals and increasing flight frequencies. In such periods of price rivalry, the larger incumbent airline may well lose money, but once the new entrant has been forced to exit the market it can increase prices and reduce flight frequencies ${ }^{4}$. While predatory behaviour is prohibited by antitrust authorities, Goetz (2002) documents a number of cases, including that of American Airlines following the entry of Vanguard Airlines on routes departing from Dallas-Forth Worth airport. Ecker and West (2006) describe a case in which Lufthansa was held to have been guilty of predatory behaviour in competition with a charter airline, Germania, on routes from Frankfurt and Berlin.

However, the difficulties encountered by antitrust authorities in distinguishing predatory behaviour from sound price competition means that incumbent airlines are quite likely to adopt such behaviour. Indeed, the predatory behaviour of incumbents is a key issue when investigating competition in the airline market.

\footnotetext{
4 As Motta 2004 points out: "yet, although rare, there are circumstances where a dominant firm might set low prices with an anti-competitive goal: forcing a rival out of the industry or pre-empting a potential entrant". This provides a good definition of predatory behaviour.
} 


\section{Data}

Below we describe the data used in our empirical analysis. The dataset comprises 25 domestic routes departing from Barcelona airport; while the time period considered runs from summer 2003 to summer 2009. The frequency of the data is semi-annual so that we differentiate between summer and winter seasons.

Various types of airline operate on the routes considered here: the former flag carrier, Iberia - a network carrier and a member of Oneworld; two smaller carriers that share certain features with the network carriers, Spanair and Air Europa - members of Star Alliance and SkyTeam, respectively; and, finally, two low-cost carriers, Clickair - created as a subsidiary of Iberia, and Vueling - an independent company until its merger with Clickair in 2009. Since that date, Vueling has been a subsidiary of Iberia.

Our price data refer to the lowest mean round-trip price charged by airlines offering services weighted by their corresponding market share. We collect price data for a sample week following these homogeneous rules. Price data refer to the city-pair link that has as its origin the city with the largest airport. Additionally, data were collected one month before travelling - the price referring to the first trip of the week, with the return journey on a Sunday. We imposed these conditions on all the routes and airlines, taking into account that our multivariate analysis exploits the variability of data across routes.

Data for the departures of each airline on each route were collected in the same sample week as that for the information collected for prices. Furthermore, we used data for the annual departures of each airline operating at Spanish airports.

The demand variable at the route level refers to the total number of passengers carried by airlines on the route, including direct and connecting traffic. The variables that correlate highly with demand at the route level are the following: 1) Population: Mean population in the provinces in which the route's origin and destination are located (NUTS 3). 2) Gross domestic product per capita (GDPc): Mean gross domestic product per capita in the regions in which the route's origin and destination are located (NUTS 2). 3) Tourism (Tour): Number of tourists per capita in the region of destination (NUTS 2). ${ }^{5}$

${ }^{5}$ NUTS is the statistical measure used by Eurostat to define regions. The NUTS classification divides up the economic territory of the Member States. The objective is to harmonize the statistical system of geographical areas across European Union countries. Hence, NUTS 2 should refer to areas with a range of population between 800,000 and 3,000,000 inhabitants. In practice, the statistical territorial units are defined in terms of the existing administrative units in the Member 
Finally, the distance variable is computed as the number of kilometres on the flight path between the origin and destination airports.

Various sources were used for data collection. Data on prices came from the airlines' websites, while data on the departures of each airline on each route were obtained from the Official Airlines Guide (OAG) website. Furthermore, information about annual departures of each airline operating at Spanish airports and information about demand at the route level were collected from the airport operator's website: Aeropuertos Españoles y Navegacion Aérea (Spanish Airports and Air Navigation, AENA). Data for population and gross domestic product per capita in the provinces and regions of the route's origin and destination were obtained from the National Statistics Institute (INE), while data of tourists per capita were taken from the Institute for Tourism Studies (IET). Finally, flight distance data were collected from the WebFlyer site.

Figures 1 and 2 provide descriptive information for the 25 routes that we consider in the empirical analysis. These two figures show that route traffic density is particularly high on routes to the largest Spanish cities (Madrid, Sevilla and Bilbao) with the exception of Valencia, which is too close to Barcelona, and that it is also particularly high on routes to major tourist destinations such as Palma de Mallorca and Málaga. Iberia and its partners (Clickair before 2009 and Vueling after that date) enjoy a high market share on both the dense routes in our sample (with the exception of Sevilla) and on the thin routes, such as those to Valladolid, León, and Valencia.

\section{Insert figure 1 about here}

\section{Insert figure 2 about here}

\section{Price rivalry in the Spanish airline market}

Table 1 records data describing route characteristics such as traffic density, distance, and the intensity of competition - all of which are useful for our purposes here. First, we should mention the great diversity in the routes under consideration, at least in terms of their traffic density and distance. For example, our analysis includes one of the densest routes in the world, Barcelona-Madrid, with more than 2 million passengers per season (six months)

States and do not necessarily meet that population range. For Spain, NUTS 2 are "Comunidades Autónomas" and NUTS 3 are "provincias". 
and a weekly frequency of 400 . This dense route mainly serves business passengers, while the other dense routes tend to cater for tourists, e.g., the link between Barcelona and Palma de Mallorca carries more than 800,000 passengers per season and has a weekly frequency of 150. By contrast, our sample of routes also includes very thin routes, such as those that link Barcelona with San Sebastián or Santander, with fewer than 40,000 passengers per season.

\section{Insert table 1 about here}

In terms of distances, planes on routes to the Canary Islands cover more than 2,000 kilometres. By contrast, intermodal competition from rail and road can be strong on routes of 300 kilometres or less (as is the case of destinations such as Valencia and Zaragoza) and also on the route to Madrid where high-speed train services have been in operation since 2008. A further three route types can be differentiated on the basis of competition in the period considered. First, there are six thin routes covered by airlines that enjoy a monopoly (Almeria, Pamplona, San Sebastián, Santander, Vitoria, and Zaragoza) ${ }^{6}$, and there are two more thin routes (León and Valladolid) where a regional airline, Lagun Air, provides some flights during some of the seasons included in our analysis.

Second, there are nine routes where the market has shifted from a monopoly to an oligopoly in the period considered. On five of these routes (Alicante, Granada, Jerez, Santiago, and Sevilla) the shift has been a consequence of the entry of the low-cost airline, Vueling. In other cases, it has involved the entry of the network airline Spanair, as well. On the other four routes (A Coruna, Oviedo, Valencia, and Vigo) the increased competition is due to the entry of Spanair.

Third, we have eight dense routes (Bilbao, Gran Canaria, Ibiza, Madrid, Málaga, Menorca, Palma de Mallorca, and Tenerife) that can be denoted as oligopoly routes in each of the periods considered. Vueling has operated services on each of these routes from 2004 or 2005 with the exception of the long-haul routes from Barcelona to the Canary Islands.

Note that Clickair started its operations at Barcelona airport in 2007, while the new Vueling, resulting from the merger between Clickair and Vueling, started its flights in mid2009.

Figures 3 and 4 show the pricing evolution for each airline in terms of mean price per kilometre and the coefficient of variation of their prices over the period. Each point in the

\footnotetext{
${ }^{6}$ On the latter two routes, there are no flights in some of the periods considered here.
} 
figures indicates the position of each airline in terms of its mean price and its coefficient of variation for the period specified in brackets. We use arrows to indicate the evolution in the prices of Iberia and its subsidiaries over time. Figure 3 shows, first of all, how Iberia's prices evolved with the shift from a monopoly to an oligopoly, and then how they subsequently evolved when Iberia become an LCC under the brand of Clickair. It also shows the evolution in Iberia's prices when Clickair merged with Vueling. Figure 4 shows how Iberia's prices evolved when it became an LCC under the brand of Clickair on routes that remained oligopoly routes throughout the period of study. ${ }^{7}$ Finally, it also shows the price evolution following Clickair's merger with Vueling. Note that letters in boldface refer to the summer season.

For clarity of discussion, below we select a number of routes that can be considered representative in that they illustrate a general pattern for the rest of the routes. As explained above, we distinguish two sets of route: first, those that moved from being a monopoly to an oligopoly, and second, routes that remained oligopolistic throughout the period ${ }^{8}$.

\section{Insert figure 3 about here}

\section{Insert figure 4 about here}

Figure 3 shows the evolution in prices on representative routes that moved from being monopolies to oligopolies. We see that Iberia cut its fares when other airlines entered the route. However, Iberia was not always able to charge lower prices than those charged by its rivals, in particular those set by Vueling. Once Iberia was substituted by Clickair, prices were reduced in relation to those of Iberia, and Clickair tended to charge similar prices to those of its cheapest rival.

Some evidence of predatory behavior can also be inferred from Figure 3, as Vueling is charging higher prices since the merger (in the summer of 2009) than Vueling and Clickair were before they joined forces (before the summer of 2009).

\footnotetext{
${ }^{7}$ Figures for the rest of the routes are available upon request from the authors.

8 A monopoly route is understood to be one on which only one airline offers a service, whereas an oligopoly route has two or more airlines offering their services. Although the Spanish airline market is liberalized (see Fageda, 2006), there are several routes that are currently operated by a single firm, usually Iberia, acting as a monopolist. On other routes, typically those with a greater density of traffic, more airlines operate, although Iberia and Spanair enjoy the greatest market shares. Among other variables, the number of airlines operating on a particular route affects the pricing of firms, as we shall see below.
} 
Three of the four routes presented in Figure 3 show a pattern of prices that would seem to be illustrative of predatory pricing behavior. On the Barcelona-Alicante route, Iberia lowered its prices by $27.6 \%$ to compete with Spanair and later Iberia, through its low-cost subsidiary, reduced its prices by $54.3 \%$ to compete with Vueling. Once the merger had occurred and Vueling was controlled by Iberia, this airline raised its prices by $67.7 \%$. A similar price pattern can be observed on the Barcelona-Seville route, where Iberia lowered its prices by $40.9 \%$ and $19.3 \%$ in competition with Spanair and Vueling respectively, but then raised its prices by $93.9 \%$ after the merger. Finally, on the Barcelona-Santiago de Compostela route prices fell by $29.8 \%$ and $22.6 \%$ with the entry respectively of Spanair and Vueling and increased by $80.9 \%$ when Iberia took control of Vueling. Thus, on these three routes, the pricing behavior of Iberia and its low-cost subsidiary presents many features of predatory pricing behavior: constant price reductions until the competitor (in this case Vueling) is removed from the market followed by significant price increases. However, given that we only have data for one period after the merger, we should exercise some caution before claiming that Iberia has displayed predatory behavior.

An additional aspect highlighted by Figure 3 is the positive relationship between Iberia's market share and its ability to set the lowest price in the market on several routes. A good example of this is on the Barcelona-Alicante route where Iberia enjoys on average a higher than 50 percent market share and fixes its price below those of its competitors. Other routes displaying this same pattern are: Barcelona-Valencia and Barcelona-La Coruña. However, Iberia does not charge less than its rivals on those routes where it does not enjoy a 50\% market share. This is the case of the Barcelona-Sevilla route (see Figure 3) and the Barcelona-Granada and Barcelona-Jerez routes. However, the relationship between Iberia's market share and its ability to fix the lowest price is not entirely clear as other routes present a different price pattern, most notably Barcelona-Oviedo and BarcelonaVigo. Yet, in Section 5 below, we are able to confirm that there is a positive relationship between Iberia's market share and its ability to fix the lowest price in the market by estimating an equation that effectively relates its prices with market shares, after controlling for several other variables.

Figure 4 shows the evolution in prices on representative routes that remained oligopolies throughout the study period. First, we must turn our attention to the route Barcelona-Madrid, which presents a number of special features in our context. The Barcelona-Madrid route is one of the densest in the world and is the only route in our 
sample where connecting traffic plays an important role. Traffic on the rest of the routes involves primarily point-to-point services, since indirect flights are clearly poor substitutes for non-stop flights on short-haul routes. However, Barcelona is Iberia's most important spoke feeding into its hub at Madrid-Barajas.

This explains why the Barcelona-Madrid route is the only route departing from Barcelona on which Iberia did not operate the Clickair brand during the period under consideration. In fact, Iberia continued to service this route with its high-frequency air shuttle services. Note also that since 2008 this route has suffered from strong intermodal competition when high-speed train services began operating with great success. If we take these features into account, Iberia charges higher prices than those charged by its rivals, but the new Vueling charged very low prices in the summer of 2009 (following the merger with Clickair). Thus, Iberia currently operates on the densest route in Spain's domestic market with two differentiated services: 1) Iberia's high quality and high frequency service, and 2) Vueling's low price service.

The pattern of prices charged by Iberia and Clickair on routes that remained oligopolies is similar to that described above for routes that moved from a monopoly to an oligopoly. On routes that remained oligopoly routes, Clickair charges lower prices than Iberia. However, Clickair's pricing seems to be less aggressive than on the routes described above (see Figure 3). Indeed, we find that Clickair may, in fact, be charging prices that are both lower and higher than those of their rivals. Exceptions are the routes to Menorca and Ibiza (the latter is shown in Figure 3), where Clickair is as aggressive in its pricing as in the previous analysis. Note also that following the merger with Clickair, Vueling charges higher prices than those charged by the merging firms.

Once again on some oligopoly routes we encounter pricing strategies that might qualify as being illustrative of predatory pricing behavior. The market entry of Vueling induced Clickair to lower its prices by $49.8 \%$ on the Barcelona-Ibiza route, $39.1 \%$ on the BarcelonaBilbao route, $16.9 \%$ on the Barcelona-Málaga route and 38.6\% on the Barcelona-Menorca route. However, when Vueling was acquired by Iberia, the company increased its prices at a much higher percentage rate $(69.1 \%, 45.4 \%, 93.5 \%$ and $53 \%$ respectively). Thus, Iberia's price strategy seems to fit into a pattern of predatory pricing, since it lowers prices until its main rival is removed from the market and then raises them significantly. 
In the case of the oligopoly routes, a positive relationship can also be observed between Iberia's market share and its ability to set the lowest market price. This relationship can be seen on the Barcelona-Ibiza, Barcelona-Málaga and Barcelona-Gran Canaria routes, where Iberia does not reach $50 \%$ of the market share and is not able to set the lowest prices. This same pattern is observed on the Barcelona-Menorca and Barcelona-Tenerife routes. As we mentioned above, this relationship is tested econometrically in a multivariate equation model in Section 5.

In this same vein, we estimate a pricing equation in the following section that examines the factors that explain the price differentials between Iberia (and its subsidiaries) and its rivals. By so doing we wish to identify whether route characteristics (traffic density, distance) and airline attributes (market share) play a role in accounting for Iberia's pricing strategy.

\section{The empirical model}

Here we estimate a pricing equation for domestic routes departing from Barcelona airport. We consider both mean prices (in nominal euros) at the route level and price differentials between Iberia and its rivals. Thus, we conduct two regressions with two different purposes. In the first regression, the dependent variable is the mean market prices at the route level, and all the routes in our sample are considered. In the second regression, the dependent variable is the price differential between Iberia and the rest of the airlines that compete on the routes included in our sample. In this second regression, we focus our attention on oligopoly routes.

We use the same explanatory variables in both regressions. First, we consider the variables that may influence airline costs at the route revel: route distance and route traffic density. Second, we consider variables related to the intensity of competition: the airlines' market shares and a dummy variable that takes a value of 1 when Iberia operates in the market as an LCC. Finally, we include a dummy variable that takes the value 1 in the summer season (from April to October). This latter variable seeks to capture differences between the summer and winter seasons.

Below, we explain the goals of each regression estimation and the expected signs of the explanatory variables considered.

\section{- The mean market price equation}


This equation seeks to examine the influence of variables such as competition and rivalry between LCCs on the mean prices charged on the route. To achieve this, we estimate the following pricing equation for route $k$ during period $t$.

$$
p_{k t}^{\text {mean }}=b_{0}+b_{1} Q_{k t}+b_{2} \text { dist }_{k}+b_{3} H H I_{k t}+b_{4} D_{k t}^{\text {Iberia_LowCost }}+b_{5} D_{k t}^{\text {summer }}+e_{k t}
$$

where the dependent variable is the mean prices weighted by the market share of each airline. These are the explanatory variables and their expected sign:

1) Route traffic density $(Q)$ : The expected sign of the coefficient of this variable is ambiguous. Greater route traffic density may lead to a better exploitation of density economics but higher demand levels may also lead airlines to charge higher mark-ups over costs.

2) Distance (dist): Distance is a major determinant of the costs that an airline has to meet when providing services on a particular route. Furthermore, intermodal competition will be more relevant on shorter routes. Thus, the sign of the coefficient of this variable should be positive.

3) Route concentration (HHI): the Herfindahl-Hirschman Index at the route level. This concentration index is calculated on the basis of the number of departures an airline operates on the route as a share of the whole. This variable allows us to measure the influence of the intensity of competition on the prices charged by an airline. When a lower degree of competition increases these prices, the sign of the coefficient associated with this variable should be positive.

4) $\mathrm{D}^{\text {Iberia_LowCost }}$ : This variable captures the influence on prices of Iberia's strategy to set up an LCC subsidiary to compete with its rivals. We expect a negative sign for this variable since price rivalry between LCCs should lead to lower prices.

- The price differential between Iberia and its cheapest rival on the route equation.

This equation seeks to examine the route characteristics that determine the ability of Iberia to charge lower (or higher) prices than those of its rivals. To do this, we estimate the following equation for route $k$ during period $t$ :

$p_{k t}^{\text {differential_Iberia }}=c_{0}+c_{1} Q_{k t}+c_{2}$ dist $_{k}+c_{3}$ Share_Iberia ${ }_{k t}+c_{4} D_{k t}^{\text {tberia_LowCost }}+c_{5} D^{\text {summer }}+e_{k t}$ 
Note that the dependent variable is the price differential between Iberia and its cheapest route competitor. Thus, this dependent variable can take either positive or negative values. In this regard, a negative coefficient of an explanatory variable implies that the higher the value of this explanatory variable, the greater is Iberia's ability to charge lower prices than its rivals. By contrast, a positive coefficient of an explanatory variable means that Iberia may not be charging lower prices than those of its rivals when the value of this variable is high. These are the explanatory variables in Equation (2) and their expected sign:

1) Route traffic density $(Q)$ : The expected sign of the coefficient of this variable is positive. Pricing rivalry between Iberia and its route competitors may not be so intense on thick routes. Indeed, Iberia may find it unnecessary to conduct an aggressive pricing policy on routes with higher route traffic densities, as there may well be room for several airlines to obtain profits.

2) Distance (dist): The expected sign of the coefficient of this variable is unclear. As distance is a major determinant of prices in absolute values, price differences between airlines should be higher in absolute values on longer routes, but this may mean Iberia charges either lower or higher prices in comparison to those of its rivals. In addition, intermodal competition on shorter routes means that the prices charged by other means of transport (trains or buses) have an effect on Iberia's price strategy.

3) Iberia's share: This is Iberia's share in terms of flight frequencies over the total frequencies on the route per period. The expected sign of the coefficient of this variable is unclear.

On the one hand, a higher market share means that the network carrier is able to exploit its cost economies more efficiently due to a more intense utilization of planes and crew or the fact of being able to share fixed costs among a large number of passengers. Likewise, higher frequency may also mean demand is higher (that is, more than in proportion to the capacity offered on the route), since a higher frequency may be more convenient for passengers. Indeed, a higher frequency reduces the schedule delay cost, i.e., the difference between the preferred time for departure and the actual time of departure. Thus, a higher frequency may help the airline to enjoy higher load factors. 
On the other hand, a higher market share may mean that the network carrier has a higher market power on the route. An airline with market power is able to charge higher prices in comparison to marginal costs.

If the cost effect dominates, then Iberia would charge lower prices when it has a higher market share on the route. By contrast, if the market power effect dominates then Iberia would charge higher prices when it has a higher market share on the route.

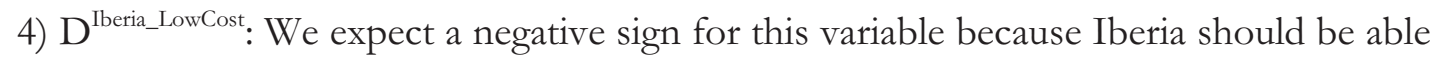
to charge lower prices when it operates the route through its low-cost subsidiary than when it operates the route with the main brand. Note that as an LCC, Iberia may reduce some costs such as those related to simpler management procedures (no business class, one single plane type, no connecting traffic, etc.) and, in particular, those related to labour since the new LCC will be less conditioned by the unions.

Note that in both regressions we include a dummy variable, as mentioned above, to account for differences across seasons.

\section{- Results and discussion}

Table 2 shows the descriptive statistics for the variables used in the empirical analysis. Taking the mean data for the whole period, it seems that Iberia charges higher prices than its rivals. However, the mean figure does not allow any changes in Iberia's pricing strategy following the entry of a new LCC in the market to be identified.

\section{Insert table 2 about here}

We estimate the pricing equation using the two-stage least squares estimator (2SLS-IV) since two explanatory variables, demand and route concentration, may be endogenous. Indeed, the simultaneous determination of prices and demand may occur and entry patterns on a route will also be influenced by the prices charged for that route. We use the following instruments for the demand variable computed for the mean value at both route endpoints: population, gross domestic product per capita, and intensity of tourism. The instrument for route concentration is concentration at the airport level. Table 3 shows the results of our estimates.

\section{Insert table 3 about here}

When estimating Equation (1), which incorporates the mean market price at the route level as its dependent variable, we find that prices increase as market concentration 
becomes higher. This means that lower levels of competition lead, as expected, to higher prices. Additionally, the volume of route traffic does not seem to have a clear effect on prices. On thick routes, the potential exploitation of density economies may be compensated by higher mark-ups over costs. Furthermore, prices are, as expected, higher on longer routes, while they also seem to be higher during the summer season.

Significantly, we find that Iberia's prices are lower when operating on the route as an LCC. If we compute the impact of this effect in terms of elasticities, we see that the entry of Iberia as an LCC involves an average price reduction of about 31.75 euros.

Taking this into account, the results of Equation (2) are also significant. Recall that Equation (2) uses the price differential of Iberia in relation to its cheapest rival as the dependent variable. The results from this equation indicate that when Iberia shifts from being a traditional carrier to an LCC it is able to charge lower mean prices than those set by its rivals - the price differential being around 63.38 euros. These figures are quite high and would seem to provide additional evidence of the predatory behaviour of the former Spanish flag carrier on routes departing from Barcelona airport. Indeed, Iberia, through its low-cost subsidiary, may have been charging these low prices to drive its main rival, Vueling, out of the market. Indeed, the profits posted by Vueling fell dramatically following the entry of Clickair on many of the routes on which it was operating. Thus, Vueling had no alternative other than to merge with Clickair. As discussed above, however, the prices charged by Iberia's low-cost subsidiary have increased substantially following the merger with Vueling.

Iberia's ability to charge lower prices than those charged by its rivals increases as the airline enjoys a higher market share. As discussed above, a higher market share may mean that a network carrier is able to exploit its cost economies more efficiently owing to a more intensive use of planes and crew, the sharing of fixed costs among a large number of passengers or the fact that greater flight frequency ensures the airline has higher demand. Alternatively, a higher market share may mean that the network carrier enjoys greater market power on the route so that it can charge higher mark-ups over marginal costs. Our results seem to suggest that the cost effects override those of market power. Indeed, Iberia can charge low prices on routes where it enjoys a high market share because of its better exploitation of cost economies. 
Finally, the pricing policy of the former Spanish flag carrier seems to be more relaxed on longer routes. By contrast, on short-haul routes intermodal competition means that price rivalry is especially intense. We also find that Iberia operates a less aggressive pricing policy on routes with higher traffic density and so there would seem to be room available for several airlines to operate services on thick routes.

In short, while previous analyses of the establishment of low-cost subsidiaries by network carriers have failed to find evidence that such a strategy might be successful, our empirical analysis of a network airline shows the opposite: Iberia has been successful in competing with an LCC via its low-cost subsidiary, Clickair, in the Spanish domestic market. Two caveats, however, should be recorded with respect to this result.

First, our analysis may only be useful for examining the competition between the subsidiary of a network carrier and a relatively small LCC. It seems likely that our results would be different if the network carrier had to compete with one of the larger LCCs in Europe, such as Ryanair or EasyJet.

Second, the Spanish network carrier has been able to fully differentiate its services from those of the low-cost subsidiary because it enjoys a dominant position in two of the largest airports in Europe, Madrid and Barcelona, which are located relatively close to each other. Indeed, the network operations of Iberia are concentrated in Madrid airport while its lowcost activities are concentrated in Barcelona airport.

Our analysis also provides some evidence to suggest that the Spanish network airline may have adopted predatory behavior.

\section{Concluding remarks}

In Europe, LCCs are capturing higher and higher market shares on most domestic and intra-European routes. In response, network airlines are being forced to adopt some of the management practices previously developed by their LCC competitors, such as no free onboard frills, the elimination of business class, and the increased utilization of planes and crew. A further step for network airlines might involve their creating low-cost subsidiaries that can compete on equal terms with their low-cost rivals.

In this paper, we have examined a successful strategy of just this kind implemented by the former Spanish flag carrier, Iberia, on routes departing from Barcelona airport. 
Our analysis reveals that Iberia created a low-cost subsidiary (Clickair) to enable it to compete with a formidable low-cost competitor in the Spanish market (Vueling). While operating as Iberia, the former Spanish flag carrier was restricted in its attempts to charge lower prices than those of its rivals. As Clickair, however, Iberia was able to charge very low prices. Our data show that the head-to-head competition between Clickair and Vueling led to a substantial reduction in prices on the routes in which both companies operated.

However, following the merger of the two companies there would seem to have been a substantial increase in the prices charged by Iberia's subsidiary, which would point towards predatory behaviour - generally regarded as an anti-competitive practice. Indeed, the European Commission agreed to the merger between Clickair and Vueling on the proviso that some slots on certain routes were transferred to other airlines (case $\mathrm{N}^{\circ}$ COMP/M.5364 -Iberia/Vueling/Clickair). It would appear that a merger appraisal should also include the evaluation of predatory practices by the firm acquiring its rival.

The estimation of the pricing equation indicates that the pricing strategy of Iberia is especially aggressive in the sense that it charges considerably lower than average prices in the following circumstances. First, Iberia charges lower prices when it has a high market share on the route. Hence, only network airlines that have a strong position in the market can compete with low-cost airlines. Second, as expected, Iberia reduces its prices substantially when it operates the route through a low-cost subsidiary. Finally, Iberia's pricing policy seems to be more aggressive on short-haul and thin routes. In the short term, passengers flying in these two types of routes may have benefited from the pricing rivalry that has arisen between airlines. With the elimination of a serious competitor, it is not clear whether Iberia (and its partners) will continue to charge low prices.

Clearly, the key to the success of Iberia's strategy has been the dominant position it has enjoyed at two of Europe's largest airports, which has seen the company concentrate its network operations in Madrid and its low-cost operations in Barcelona. Here, it should be noted that airports in Spain are managed on a centralized basis so that a decision taken by a manager at any one of the country's airports needs to consider its ramifications for all other Spanish airports. This might explain why the Spanish airport operator did not intervene in the transfer of slots from Iberia to Clickair, even though Iberia was a very important, albeit not the sole, shareholder in Clickair. What is not so clear is whether the airport manager at 
Barcelona airport would have stood by and let a network carrier be substituted by a lowcost carrier in a situation where airport management is made on an individualized basis.

Finally, we are unable to conclude that the pricing strategy of the network carrier discussed here would be successful if the rivals were leading LCCs, such as Ryanair or EasyJet, rather than a domestic LCC. Our analysis seems to indicate that only the major LCCs can compete with network airlines in short-haul markets. If this were to be the case, then we can expect further consolidation and increased concentration in the airline industry. This tendency is more than apparent when we consider network airlines, as amply demonstrated by the mergers of Air France with KLM and Lufthansa with Swiss and the expected merger of British Airways with Iberia. In the LCC arena too, the leading players may also take on a growing role.

\section{References}

Alderighi, M., Cento, A., Nijkamp, P., Rietveld, P., 2004. The entry of low cost airlines, Tinbergen Institute Discussion Paper TI 2004-074/3.

Borenstein, S., 1989. Hubs and High Fares: Dominance and Market Power in the U.S Airline Industry. Rand Journal of Economics, 20, 344-365.

Dresner, M., Chris Lin, J.S., Windle, R., 1996. The impact of low-cost carriers on airport and route competition. Journal of Transport Economics and Policy, 30, 309-329.

Dobruszkes, F., 2009. New Europe, new low-cost air services. Journal of Transport Geography, 17, 423-432.

Eckert, A. and West, D.S. "Predation in Airline Markets: A Review of Recent Cases", Advances in Airline Economics, Volume 1: Competition and Antitrust, Darin Lee (ed.), Amsterdam: Elsevier, (2006), pp. 25-52.

Fageda, X., 2006. Measuring conduct and cost parameters in the Spanish airline market. Review of Industrial Organization, 28 (4), 379-399.

Fageda, X., Fernandez-Villadangos, L., 2009. Triggering competition in the Spanish airline market: the role of airport capacity and low cost carriers. Journal of Air Transport Management, 15, 36-40.

Gaggero, A.A, Piga, C.A., forthcoming. Airline competition in the British Isles. Transportation Research-E, forthcoming. 
Graham, F., Humphreys, I., Ison, S., Aicken, M., 2006. Where next for low cost airlines? A spatial and temporal comparative study. Journal of Transport Geography, 14, 83-94.

Graham, B., Vowles, T.M. 2006. Carriers within carriers: A strategic response to low-cost airline competition. Transport Reviews, 26, 105-126.

Goetz, A.R., 2002. Deregulation, competition, and antitrust implications in the US airline industry. Journal of Transport Geography, 10, 1-19.

Goetz, A.R, Vowles, T.M., 2009. The good, the bad and the ugly: 30 years of US airline deregulation. Journal of Transport Geography, 17, 251-263.

Morrell, P., 2005. Airline within airlines: An analysis of US network airline responses to Low Cost Carriers. Journal of Air Transport Management, 11, 303-312.

Morrison, S.A., 2001. Actual, Adjacent, and potential competition: Estimating the full effect of Southwest airlines. Journal of Transport Economics and Policy, 35, 239-256.

Motta, M. "Competition Policy: Theory and Practice", New York: Cambridge University Press, (2004).

Vowles, T.W., 2000. The effect of low fare air carriers on airfares in the US. Journal of Transport Geography, 8, 121-128.

Vowles, T.W., 2006. Airfare pricing determinants in hub-to-hub markets. Journal of Transport Geography, 14, 15-22. 


\section{TABLES AND FIGURES}

Table 1. Descriptive statistics by route. Mean values for the period 2003-2009

\begin{tabular}{|c|c|c|c|c|c|c|}
\hline $\begin{array}{l}\text { Route from } \\
\text { Barcelona }\end{array}$ & $\begin{array}{c}\text { Traffic } \\
\text { density } \\
\text { (passengers) }\end{array}$ & $\begin{array}{c}\text { Traffic } \\
\text { density } \\
\text { (frequency) }\end{array}$ & Distance & $\begin{array}{c}\text { Average } \\
\text { competitors }\end{array}$ & $\begin{array}{c}\text { Year } \\
\text { entrance } \\
\text { Clickair }\end{array}$ & $\begin{array}{c}\text { Year } \\
\text { entrance } \\
\text { Vueling }\end{array}$ \\
\hline Alicante (ALC) & 185,735 & 40 & 404 & 1,7 & $2007, \mathrm{~W}$ & $2006, \mathrm{~S}$ \\
\hline Almería (LEI) & 47,053 & 22 & 632 & 1 & - & - \\
\hline Bilbao (BIO) & 284,997 & 54 & 467 & 2,5 & 2007, W & 2004, W \\
\hline Gran Canaria (LPA) & 143,066 & 24 & 2170 & 3,1 & 2007, W & $2009, \mathrm{~S}$ \\
\hline Granada (GRX) & 140,871 & 27 & 681 & 1,9 & $2007, \mathrm{~S}$ & $2006, \mathrm{~S}$ \\
\hline Ibiza (IBZ) & 388,828 & 75 & 276 & 3,2 & $2007, \mathrm{~S}$ & $2004, \mathrm{~S}$ \\
\hline Jerez (XRY) & 54,111 & 12 & 866 & 1,5 & $2007, \mathrm{~S}$ & $2007, \mathrm{~S}$ \\
\hline La Coruña (LCG) & 99,980 & 22 & 888 & 1,7 & $2007, \mathrm{~S}$ & $2009, \mathrm{~S}$ \\
\hline León (LEN) & 21,293 & 14 & 784 & 1,5 & - & - \\
\hline Madrid (MAD) & $2,078,867$ & 401 & 484 & 3,9 & - & 2004,W \\
\hline Málaga (AGP) & 375,289 & 65 & 765 & 2,7 & - & $2005, \mathrm{~S}$ \\
\hline Menorca (MAH) & 299,772 & 69 & 241 & 3,2 & $2007, \mathrm{~S}$ & $2005, \mathrm{~S}$ \\
\hline Oviedo (OVD) & 128,999 & 32 & 712 & 1,5 & 2007, W & $2009, \mathrm{~S}$ \\
\hline Mallorca (PMI) & 825,286 & 155 & 203 & 4,5 & 2007, W & $2004, \mathrm{~S}$ \\
\hline Pamplona (PNA) & 37,204 & 21 & 348 & 1 & - & - \\
\hline San Sebastián (EAS) & 38,061 & 20 & 392 & 1 & - & - \\
\hline Santander (SDR) & 36,289 & 20 & 539 & 1 & - & - \\
\hline Santiago (SCQ) & 145,837 & 29 & 893 & 2,2 & $2007, \mathrm{~S}$ & $2006, \mathrm{~S}$ \\
\hline Sevilla (SVQ) & 491,737 & 82 & 810 & 3,3 & $2007, \mathrm{~S}$ & 2004, W \\
\hline Tenerife (TFN/TFS) & 217,118 & 33 & 2190 & 3,2 & 2007, W & $2009, \mathrm{~S}$ \\
\hline Valencia (VLC) & 84,461 & 30 & 296 & 1,4 & - & - \\
\hline Valladolid (VLL) & 43,310 & 28 & 579 & 1,2 & - & - \\
\hline Vigo (VGO) & 104,889 & 23 & 893 & 1,7 & $2007, \mathrm{~S}$ & $2009, \mathrm{~S}$ \\
\hline Vitoria (VIT) & 7,045 & 4 & 433 & 1 & - & - \\
\hline Zaragoza (ZAZ) & 7,533 & 4 & 264 & 1 & - & - \\
\hline
\end{tabular}

Note: $\mathrm{W}$ refers to the winter season and $\mathrm{S}$ refers to the summer season.

Source: Own elaboration. 
Figure 1: Mainland routes

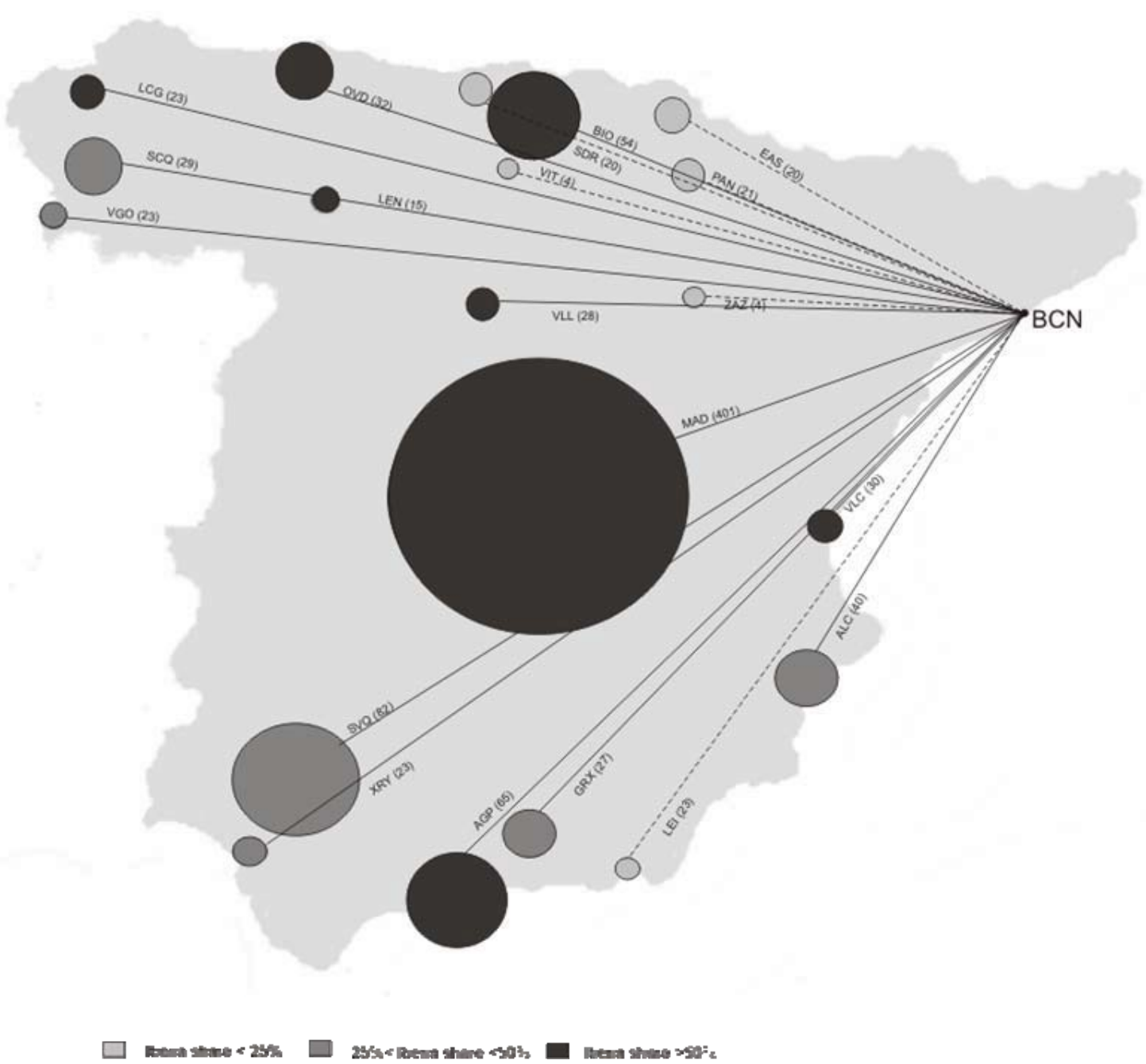

Note: The airports that are endpoints of the route are market with the IATA code. Dashed lines are monopoly routes. The diameter of each circle shows the relative amount of passengers on route. Frequency is included among brackets.

Source: Own elaboration. 
Figure 2: Island routes

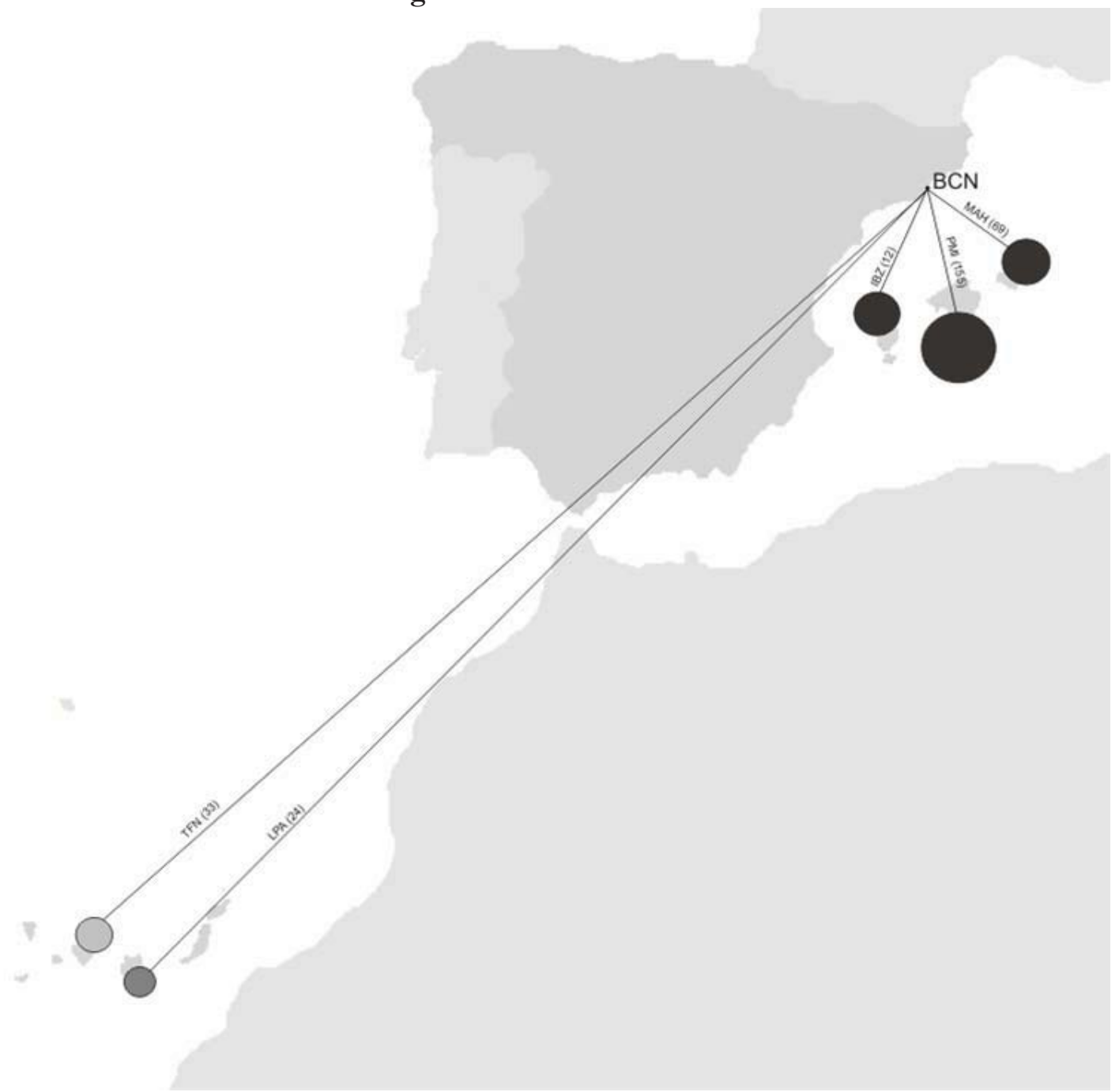

Note: The airports that are endpoints of the route are market with the IATA code. The diameter of each circle shows the relative amount of passengers on route. Frequency is included among brackets.

Source: Own elaboration. 
Figure 3. Representative routes that move from monopoly to oligopoly
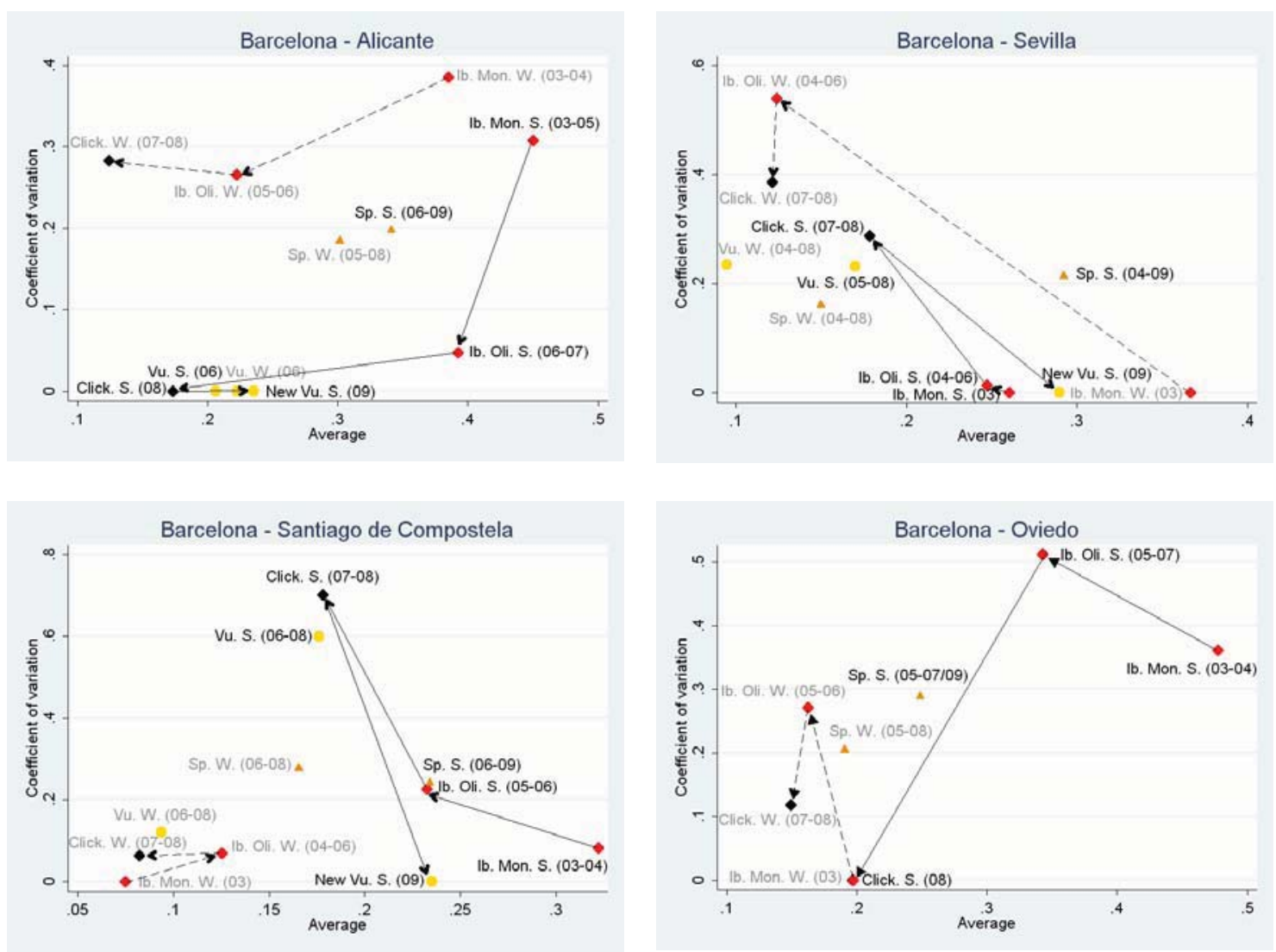

Note: In the horizontal axis, we show average prices per kilometre. In the vertical axis, we show the coefficient of variation of prices. Note that in brackets, it is indicated the period for which data for each airline is calculated. Mon. means monopoly and Oli. means oligopoly. Ib is Iberia, Sp is Spanair, Click is Clickair and Vu is Vueling. S refers to the summer season and W refers to the winter season.

Source: Own elaboration. 
Figure 4. Representative oligopoly routes in the considered period
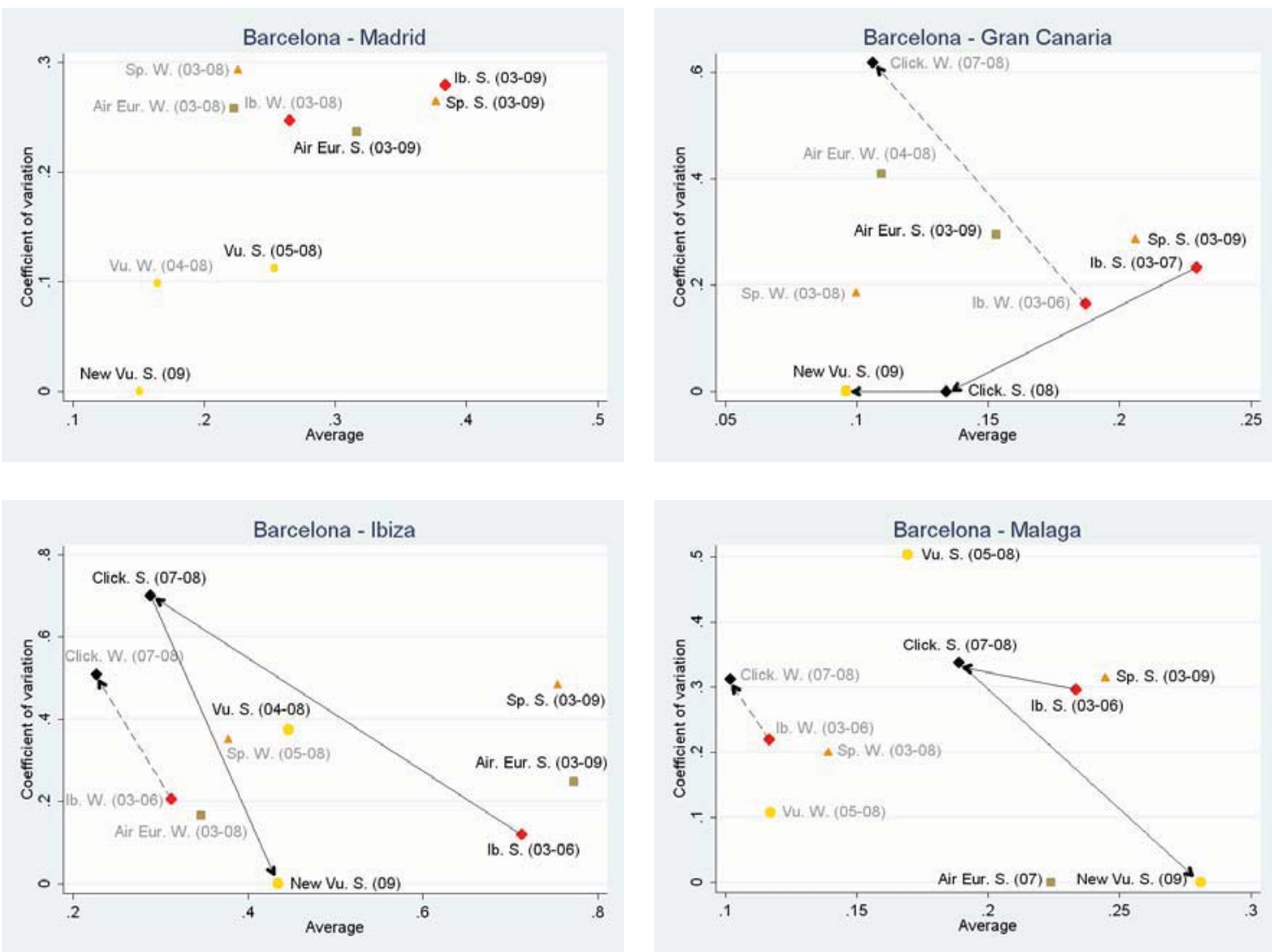

Note: In the horizontal axis, we show average prices per kilometre. In the vertical axis, we show the coefficient of variation of prices. Note that in brackets, it is indicated the period for which data for each airline is calculated. Mon. means monopoly and Oli. means oligopoly. Ib is Iberia, Sp is Spanair, Click is Clickair, Vu is Vueling and Air. Eur is Air Europa. S refers to the summer season and $\mathrm{W}$ refers to the winter season Source: Own elaboration. 
Table 2. Summary of descriptive statistics

\begin{tabular}{ccccc}
\hline Variable & Mean & $\begin{array}{c}\text { Standard } \\
\text { Deviation }\end{array}$ & $\begin{array}{c}\text { Minimum } \\
\text { Value }\end{array}$ & $\begin{array}{c}\text { Maximum } \\
\text { Value }\end{array}$ \\
\hline Market price & 193.40 & 104.72 & 54.82 & 620.44 \\
$\begin{array}{c}\text { Price differential } \\
\text { (Iberia in relation }\end{array}$ & 20.36 & 84.70 & -190.8 & 430 \\
to the cheapest & & & & \\
rival) & & & & 0.86 \\
Market share & 0.48 & 0.15 & 0.14 & \\
Iberia (route) & & & & $2,514,338$ \\
Total Traffic & $265,699.6$ & $433,320.7$ & 5,460 & 1 \\
Concentration & 0.65 & 0.28 & 0.25 & \\
Index (route) & & & & 2,190 \\
Distance & 706.96 & 495.73 & 203 & 1 \\
DIberia_Lowcost & 0.23 & 0.43 & 0 & 1 \\
Dsummer & 0.54 & 0.23 & 0 & \\
\hline
\end{tabular}

Table 3. Estimates of the pricing equation (2SLS)

Dependent variable

\begin{tabular}{ccc}
\hline $\begin{array}{c}\text { Explanatory } \\
\text { variables }\end{array}$ & $\begin{array}{c}\text { Mean market prices. All } \\
\text { routes (1) }\end{array}$ & $\begin{array}{c}\text { Price differentials (Iberia in relation } \\
\text { to the cheapest rival). Oligopoly } \\
\text { routes (2) }\end{array}$ \\
\hline $\begin{array}{c}\text { Market share } \\
\text { Iberia (route) }\end{array}$ & - & -93.18 \\
Concentration & $116.36(27.72)^{* * *}$ & - \\
Index (route) & & $-74.73)^{* *}$ \\
Total Traffic & $1.08 \mathrm{e}-06(9.36 \mathrm{e}-06)$ & $0.000014(7.92 \mathrm{e}-06)^{*}$ \\
$(Q)$ & $0.11(0.01)^{* * *}$ & $0.04(0.01)^{* * *}$ \\
Distance & $-31.75(9.22)^{* * *}$ & $-63.76(12.34)^{* * *}$ \\
Diberia_LowCost & $80.24(8.58)^{* * *}$ & $5.76(10.94)$ \\
D summer & $0.50(23.61)$ & $50.02(27.61)^{*}$ \\
Intercept & 305 & 185 \\
Number & 0.48 & 0.27 \\
observations & $47.73^{* * *}$ & $11.24 * * *$ \\
$\mathrm{R}^{2}$ & F-test &
\end{tabular}

Note $1: * * * 1 \%, * * 5 \%, * 10 \%$ significance test.

Note 2: Instruments for total traffic and concentration index (route): population, GDP per capita, tourism intensity, concentration index (airport) 


\section{Llista Document de Treball}

List Working Paper

WP 2010/07 "Price rivalry in airline markets: A study of a successful strategy of a network carrier against a low-cost carrier" Fageda, X ; Jiménez J.L.; Perdiguero, J.

WP 2010/06 "La reforma de la contratación en el mercado de trabajo: entre la flexibilidad y la seguridad" Royuela V. and Manuel Sanchis M.

WP 2010/05 "Discrete distributions when modeling the disability severity score of motor victims" Boucher, $\mathrm{J}$ and Santolino, M

WP 2010/04 "Does privatization spur regulation? Evidence from the regulatory reform of European airports . Bel, G. and Fageda, X."

WP 2010/03 "High-Speed Rail: Lessons for Policy Makers from Experiences Abroad". Albalate, D ; and Bel, G."

WP 2010/02 "Speed limit laws in America: Economics, politics and geography". Albalate, D ; and Bel, G."

WP 2010/01 "Research Networks and Inventors' Mobility as Drivers of Innovation: Evidence from Europe" Miguélez, E. ; Moreno, R."

WP 2009/26 "Social Preferences and Transport Policy: The case of US speed limits" Albalate, D.

WP 2009/25 "Human Capital Spillovers Productivity and Regional Convergence in Spain", Ramos, R ; Artis, M. ; Suriñach, J.

WP 2009/24 “Human Capital and Regional Wage Gaps” ,López-Bazo,E. Motellón E.

WP 2009/23 "Is Private Production of Public Services Cheaper than Public Production? A meta-regression analysis of solid waste and water services" Bel, G.; Fageda, X.; Warner. M.E.

WP 2009/22 "Institutional Determinants of Military Spending" Bel, G., Elias-Moreno, F.

WP 2009/21 "Fiscal Regime Shifts in Portugal" Afonso, A., Claeys, P., Sousa, R.M.

WP 2009/20 "Health care utilization among immigrants and native-born populations in 11 European countries. Results from the Survey of Health, Ageing and Retirement in Europe" Solé-Auró, A., Guillén, M., Crimmins, E.M.

WP 2009/19 "La efectividad de las políticas activas de mercado de trabajo para luchar contra el paro. La experiencia de Cataluña" Ramos, R., Suriñach, J., Artís, M.

WP 2009/18 "Is the Wage Curve Formal or Informal? Evidence for Colombia" Ramos, R., Duque, J.C., Suriñach, J.

WP 2009/17 "General Equilibrium Long-Run Determinants for Spanish FDI: A Spatial Panel Data Approach" Martínez-Martín, J.

WP 2009/16 "Scientists on the move: tracing scientists' mobility and its spatial distribution" Miguélez, E.; Moreno, R.; Suriñach, J.

WP 2009/15 "The First Privatization Policy in a Democracy: Selling State-Owned Enterprises in 1948-1950 Puerto Rico" Bel, G.

WP 2009/14 “Appropriate IPRs, Human Capital Composition and Economic Growth” Manca, F.

WP 2009/13 "Human Capital Composition and Economic Growth at a Regional Level" Manca, $\mathrm{F}$.

WP 2009/12 "Technology Catching-up and the Role of Institutions" Manca, F.

WP 2009/11 "A missing spatial link in institutional quality" Claeys, P.; Manca, F. 
WP 2009/10 "Tourism and Exports as a means of Growth" Cortés-Jiménez, I.; Pulina, M.; Riera i Prunera, C.; Artís, M.

WP 2009/09 "Evidence on the role of ownership structure on firms' innovative performance" Ortega-Argilés, R.; Moreno, R.

WP 2009/08 “¿Por qué se privatizan servicios en los municipios (pequeños)? Evidencia empírica sobre residuos sólidos y agua” Bel, G.; Fageda, X.; Mur, M.

WP 2009/07 "Empirical analysis of solid management waste costs: Some evidence from Galicia, Spain”Bel, G.; Fageda, X.

WP 2009/06 "Intercontinental fligths from European Airports: Towards hub concentration or not?" Bel, G.; Fageda, X.

WP 2009/05 "Factors explaining urban transport systems in large European cities: A crosssectional approach" Albalate, D.; Bel, G.

WP 2009/04 "Regional economic growth and human capital: the role of overeducation" Ramos, R.; Suriñach, J.; Artís, M.

WP 2009/03 "Regional heterogeneity in wage distributions. Evidence from Spain" Motellón, E.; López-Bazo, E.; El-Attar, M.

WP 2009/02 "Modelling the disability severity score in motor insurance claims: an application to the Spanish case" Santolino, M.; Boucher, J.P.

WP 2009/01 "Quality in work and aggregate productivity" Royuela, V.; Suriñach, J.

WP 2008/16 "Intermunicipal cooperation and privatization of solid waste services among small municipalities in Spain" Bel, G.; Mur, M.

WP 2008/15 "Similar problems, different solutions: Comparing refuse collection in the Netherlands and Spain" Bel, G.; Dijkgraaf, E.; Fageda, X.; Gradus, R.

WP 2008/14 "Determinants of the decision to appeal against motor bodily injury settlements awarded by Spanish trial courts" Santolino, M

WP 2008/13 "Does social capital reinforce technological inputs in the creation of knowledge? Evidence from the Spanish regions" Miguélez, E.; Moreno, R.; Artís, M.

WP 2008/12 "Testing the FTPL across government tiers" Claeys, P.; Ramos, R.; Suriñach, J.

WP 2008/11 "Internet Banking in Europe: a comparative analysis" Arnaboldi, F.; Claeys, P.

WP 2008/10 "Fiscal policy and interest rates: the role of financial and economic integration" Claeys, P.; Moreno, R.; Suriñach, J.

WP 2008/09 "Health of Immigrants in European countries" Solé-Auró, A.; M.Crimmins, E.

WP 2008/08 "The Role of Firm Size in Training Provision Decisions: evidence from Spain" Castany, L.

WP 2008/07 "Forecasting the maximum compensation offer in the automobile $\mathrm{Bl}$ claims negotiation process" Ayuso, M.; Santolino, M.

WP 2008/06 "Prediction of individual automobile RBNS claim reserves in the context of Solvency II" Ayuso, M.; Santolino, M.

WP 2008/05 "Panel Data Stochastic Convergence Analysis of the Mexican Regions" Carrion-iSilvestre, J.L.; German-Soto, V.

WP 2008/04 "Local privatization, intermunicipal cooperation, transaction costs and political interests: Evidence from Spain” Bel, G.; Fageda, X. 
WP 2008/03 "Choosing hybrid organizations for local services delivery: An empirical analysis of partial privatization" Bel, G.; Fageda, X.

WP 2008/02 "Motorways, tolls and road safety. Evidence from European Panel Data" Albalate, D.; Bel, G.

WP 2008/01 "Shaping urban traffic patterns through congestion charging: What factors drive success or failure?” Albalate, D.; Bel, G.

WP 2007/19 "La distribución regional de la temporalidad en España. Análisis de sus determinantes" Motellón, E.

WP 2007/18 "Regional returns to physical capital: are they conditioned by educational attainment?" López-Bazo, E.; Moreno, R.

WP 2007/17 "Does human capital stimulate investment in physical capital? evidence from a cost system framework" López-Bazo, E.; Moreno, R.

WP 2007/16 "Do innovation and human capital explain the productivity gap between small and large firms?" Castany, L.; López-Bazo, E.; Moreno, R.

WP 2007/15 "Estimating the effects of fiscal policy under the budget constraint" Claeys, P.

WP 2007/14 "Fiscal sustainability across government tiers: an assessment of soft budget constraints" Claeys, P.; Ramos, R.; Suriñach, J.

WP 2007/13 "The institutional vs. the academic definition of the quality of work life. What is the focus of the European Commission?” Royuela, V.; López-Tamayo, J.; Suriñach, J.

WP 2007/12 "Cambios en la distribución salarial en españa, 1995-2002. Efectos a través del tipo de contrato" Motellón, E.; López-Bazo, E.; El-Attar, M.

WP 2007/11 "EU-15 sovereign governments' cost of borrowing after seven years of monetary union" Gómez-Puig, M..

WP 2007/10 "Another Look at the Null of Stationary Real Exchange Rates: Panel Data with Structural Breaks and Cross-section Dependence" Syed A. Basher; Carrion-iSilvestre, J.L.

WP 2007/09 "Multicointegration, polynomial cointegration and I(2) cointegration with structural breaks. An application to the sustainability of the US external deficit" Berenguer-Rico, V.; Carrion-i-Silvestre, J.L.

WP 2007/08 "Has concentration evolved similarly in manufacturing and services? A sensitivity analysis" Ruiz-Valenzuela, J.; Moreno-Serrano, R.; Vaya-Valcarce, E.

WP 2007/07 "Defining housing market areas using commuting and migration algorithms. Catalonia (Spain) as an applied case study" Royuela, C.; Vargas, M.

WP 2007/06 "Regulating Concessions of Toll Motorways, An Empirical Study on Fixed vs. Variable Term Contracts" Albalate, D.; Bel, G.

WP 2007/05 "Decomposing differences in total factor productivity across firm size" Castany, L.; Lopez-Bazo, E.; Moreno, R.

WP 2007/04 "Privatization and Regulation of Toll Motorways in Europe" Albalate, D.; Bel, G.; Fageda, $X$.

WP 2007/03 "Is the influence of quality of life on urban growth non-stationary in space? A case study of Barcelona" Royuela, V.; Moreno, R.; Vayá, E.

WP 2007/02 "Sustainability of EU fiscal policies. A panel test" Claeys, P. 
WP 2007/01 "Research networks and scientific production in Economics: The recent spanish experience" Duque, J.C.; Ramos, R.; Royuela, V.

WP 2006/10 "Term structure of interest rate. European financial integration" Fontanals-Albiol, H.; Ruiz-Dotras, E.; Bolancé-Losilla, C.

WP 2006/09 "Patrones de publicación internacional (ssci) de los autores afiliados a universidades españolas, en el ámbito económico-empresarial (1994-2004)" Suriñach, J.; Duque, J.C.; Royuela, V.

WP 2006/08 "Supervised regionalization methods: A survey" Duque, J.C.; Ramos, R.; Suriñach, $\mathrm{J}$.

WP 2006/07 "Against the mainstream: nazi privatization in 1930s germany" Bel, G.

WP 2006/06 "Economía Urbana y Calidad de Vida. Una revisión del estado del conocimiento en España" Royuela, V.; Lambiri, D.; Biagi, B.

WP 2006/05 "Calculation of the variance in surveys of the economic climate" Alcañiz, M.; Costa, A.; Guillén, M.; Luna, C.; Rovira, C.

WP 2006/04 "Time-varying effects when analysing customer lifetime duration: application to the insurance market” Guillen, M.; Nielsen, J.P.; Scheike, T.; Perez-Marin, A.M.

WP 2006/03 "Lowering blood alcohol content levels to save lives the european experience" Albalate, D.

WP 2006/02 "An analysis of the determinants in economics and business publications by spanish universities between 1994 and 2004" Ramos, R.; Royuela, V.; Suriñach, J.

WP 2006/01 "Job losses, outsourcing and relocation: empirical evidence using microdata" Artís, M.; Ramos, R.; Suriñach, J. 


\section{$\mathbb{\bigotimes}_{\mathbb{1}}|\mathrm{R}| \mathrm{E}|\mathrm{A}|$}

Institut de Recerca en Economia Aplicada Regional i Pública

Research Institute of Applied Economics

Universitat de Barcelona

Av. Diagonal, 690 • 08034 Barcelona

WEBSITE: www.ub.edu/irea/•CONTACT: irea@ub.edu 